\title{
Research on the Significance of Teaching Mode Reform of Business English Course Based on Constructivism Experience
}

\author{
Yu Zhang ${ }^{1}$ \\ ${ }^{1}$ The Engineering and Technical College of Chengdu University of Technology, Leshan, China
}

Keywords: Business English, Constructivism, Experience, Teaching Mode Reform.

\begin{abstract}
This paper explores the constructivist teaching theory, designs the experiential teaching mode, and explores the innovation of business English teaching, so as to achieve the purpose of improving the English students' business English learning efficiency. Based on the theoretical foundation, this paper analyzes the contents of business English course, and attempts to design the teaching mode of the experiential business English course, through the concrete example of the case teaching and the task teaching, and to explore the transition from the "student orientation" to the "student orientation" in the business English teaching process. The design of the curriculum mode of the experiential business English course can greatly stimulate the enthusiasm and participation of the students, improve the comprehensive quality of the students, and improve the teaching quality and teaching effect of the business English courses. Through the design and innovation of the teaching mode, it is practical to improve the teaching effect of business English courses, and provide a useful reference for the current business English teaching reform.
\end{abstract}

\section{Introduction on Business English Course}

Economic globalization has brought about the ever-changing in international and domestic environment and business environment. The trend of globalization has also put forward higher requirements to the personnel training, and the compound talents have become the talented people in the international market urgently. Many foreign language institutions in China's University have set up business English courses, in order to cultivate the needs of the international community to adapt to the complex business foreign language talents. Business English is a special purpose English (ESP) which is suitable for the training of foreign language and professional talents. It aims to improve students' ability to use English to engage in business activities and further deepen and expand the students' English knowledge, and to cultivate the compound talents with a solid professional foundation of business, a high theoretical level, a wide range of international knowledge, and is able to master the English listening, speaking, reading, writing, translation skills.

Purpose and Requirements of Business English Course. The purpose and task of business English course is to teach and train students systematically and comprehensively through the simulation of typical business scenarios, commit to expanding students' expertise in the business activities, understanding the English language skills, business knowledge and business skills. This course requires teachers to use proper teaching methods and teaching modes in the practical activities. By creating the teaching organization and simulating the real scene, teachers and students can participate actively in a large number of business practices.

Through studying business English course, students can integrate the Eastern and Western cultures in the business environment; master the English listening, speaking, reading and writing skills in business activities. Teachers can cultivate compound English professional talents who are adaptability and practical, and master a wide range of knowledge, with solid English language foundation and language application ability, and perceive professional business knowledge and communication skills, and carry out international business Activities systematically.

Teaching Contents and Hourly Assignment of Business English Course. The author takes the English majors of Foreign Languages Department of Engineering and Technical College of Chengdu University of Technology as the object of the course, under the guidance of the constructivism theory, will adapt experience method in the teaching of business English course. The teacher will apply two 
business English books in two semesters and the books are respectively written by Sarah Jones-Macziola with Greg White, authors of Further Ahead, and Leo Jones, author of Working in English. The following part is an introduction about the two books and the curriculum allocations of how to use them.

Book 1--Further Ahead. Further Ahead-a communication skills course for Business English [1], suitable for both pre- and post-experience learners, it offers units based on topics learners will meet in their daily work, such as marketing campaigns, import and export, coping with meetings and business ethics; a variety of challenging tasks and communicative activities that ensure that all four skills are developed; clearly structured and measured progression, with revision units to enable learners to check their progress; clear and accessible layout.

New features include concise grammar summaries to accompany the revision units, and a focus on building up key vocabulary. The book is accompanied by an Audio Cassette or Audio CD. The Teacher's Guide provides support and guidance, as well as a full key and typescripts. The Home Study Book offers the learner further practice to consolidate their studies.

Course components: Learner's Book, Learner's Book Cassette, Learner's Book Audio CD; Teachers' Guide, Home Study Book, Home Study Book Cassette, Home Study Book Audio CD.

Table 1. Teaching Contents and Hourly Assignment of Business English Course in Book 1.

\begin{tabular}{|l|l|c|c|}
\hline \multirow{2}{*}{ Contents } & \multirow{2}{*}{ Allocation } \\
\cline { 3 - 4 } & & Lectures & Seminars \\
\hline 1 & Meeting People & 1 & 1 \\
\hline 2 & Taking about companies & 1 & 1 \\
\hline 3 & Jobs & 1 & 1 \\
\hline 4 & Work and Play & 1 & 1 \\
\hline 5 & Transportation & 1 & 1 \\
\hline 6 & Imports and exports & 1 & 1 \\
\hline 7 & Arrangements & 1 & 1 \\
\hline 8 & Products and services & 1 & 1 \\
\hline 9 & Marketing & 1 & 1 \\
\hline 10 & Statistics & 1 & 1 \\
\hline 11 & Money & 1 & 1 \\
\hline 12 & Socializing & 1 & 1 \\
\hline 13 & Business culture and ethics & 1 & 1 \\
\hline 14 & Meetings & 1 & 1 \\
\hline 15 & Processes & 16 & 16 \\
\hline 16 & Conferences & & 32 \\
\hline & $\quad$ Total & & \\
\hline & & & 1 \\
\hline
\end{tabular}

Book 2 --Working in English. Working in English [2] is a brand new course for Business English intermediate level learners and is equally suitable for those in work or preparing for c career in business. It focuses on the day-to-day communication needs of learners and builds confidence and fluency by using every opportunity to get students to carry out tasks in English.

The course has 40 units in seven modules: Person to person, phone calls, writing, exchanging information, meetings, entertaining visitors, explaining and presenting. Each unit is a double-page spread and contains material for a 45-minite classroom session and is divided into A, B or C sections with a series of steps.

The core material can be supplemented and customized by using the extra material found in the Teacher's Book and by the content found on the Working in English CD-ROM and Website.

There is a Video containing short documentary sequences filmed in the USA and Europe designed to tie in with the content of the seven modules.

A Personal Study Book with Audio CD provides further practice for students to do on their own.

Course components: Student's Book, Student's Book Cassette Set, Student's Book Audio CD Set; Personal Study Book Audio CD, Teachers’ Guide with CD-ROM, Video, Website. 
Table 2. Teaching Contents and Hourly Assignment of Business English Course in Book 2.

\begin{tabular}{|l|l|l|l|}
\hline \multirow{2}{*}{ Contents } & \multicolumn{2}{c|}{ Allocation } \\
\cline { 3 - 4 } & & Lectures & Seminars \\
\hline 1 & Person to person & 2 & 2 \\
\hline 2 & Phone calls & 2 & 2 \\
\hline 3 & Writing & 2 & 2 \\
\hline 4 & Exchanging information & 2 & 2 \\
\hline 5 & Meetings & 2 & 2 \\
\hline 6 & Entertaining visitors & 2 & 2 \\
\hline 7 & Explaining and presenting & 2 & 2 \\
\hline 8 & Revision and consolidation & 2 & 2 \\
\hline \multicolumn{2}{|l}{} & 16 & 16 \\
\hline Total & 32 & \\
\hline
\end{tabular}

\section{The Overview of Constructivist Theory}

Constructivism is a complex social science theory emerging from contemporary European and American countries. Its earliest initiators can be traced back to Piaget, the famous psychology in Switzerland. He believes that "knowledge is neither from the subject nor from the object, but through the interaction between the subject and the object, the processes of constructing knowledge is building up”. [3]

Constructivism believes that learning is not a passive acceptance of information, but the learners in a certain context, that is, social and cultural background, by using learning strategies, by actively discovering problems and research problems, and with the existing knowledge and experience and the surrounding environment to solve the problem, and ultimately achieve the meaning of the construction.

The core content of applying constructivism into foreign language teaching can be summarized as: student-centered, emphasizing students' active exploration of knowledge, active discovery and active construction of knowledge.

Learning is a process of constructing mental representation, learners do not move knowledge from the outside into memory, but on the basis of existing experience through the interaction with the outside world to obtain the process of building new knowledge, knowledge is not through teachers to teach, but the learners in a certain situation that the social and cultural background, with the help of others' (such as teachers and fellow students) collaboration and help, use the necessary learning materials (such as text, images, physical, network and other media), the task of management learning gradually transferred from the teacher to the students themselves.

\section{The Core Concept of Experiential Foreign Language Teaching}

The starting point of experiential foreign language teaching is to pay attention to the problem of lack of learning confidence and lack of learning motivation in foreign language learning. The basic concept is to take learners' positive psychological experience as the driving force and orientation, with the situation, interaction, task or project, cooperative learning as the main method, assisted with modern information technology integration of foreign language teaching resources, to build a foreign language learning environment.

Through participating in certain foreign language learning environment, emphasizing students' “engagement”, “enjoyment”, “enhancement” [4], experience learning and teaching mode can help learners deeply involved in the foreign language and therefore master language communication competence. Experiential Teaching in Business English should pay attention to the following problems.

Prepare for Students. Students are the main body of classroom learning, but also the object of classroom teaching. The preparation of students is the foundation and core of the whole experiential teaching. Students are differential in learning ability, English level, cognitive style, learning attitude and so on, thus need teachers to carefully notice their difference and understand this distinction. [5] 
Teachers should grasp the characteristics of student groups, make good use of the advantages of situation and case in classroom teaching, rouse the students' subjectivity and initiative, and actively encourage and cultivate students' practical ability.

Preparation for Context and Case. It is important to set up a simulated business situation and choose a good case. Teachers should pay attention to the principle of relevance when setting up business environment and selecting business transaction cases. All situations and cases should come from business reality, refining the actual business activities, and cannot be made up. Teachers should be familiar with the business situation and the case of the material, making clear the entire teaching process, through teaching the business case to achieve the teaching objectives of business English.

Preparation for Classroom Activities. On the design of classroom discussion and experiential teaching, in addition to group discussions, there are case observation, role play, and situational experience, and ect. These activities take a lot of time in the classroom, and need for careful consideration of possible situations and coping strategies when designing and organizing these activities.

\section{Designing Experiential Teaching Activities of Business English}

Simulation of Situational Experience. Simulation of the situation experience method refers to by some teaching software--CD-ROM, courseware and other multimedia technology, or the use of pictures, video and other physical, students simulate business situations as realistic as possible, so that students have immersive feeling, and participate effectively in the learning process.

This kind of experiential teaching method is suitable for the content of the text which is mainly composed of business contacts and business negotiations.

Role-playing Experience. Role-playing experience is that students play a variety of roles and get into the roles to deal with various business problems and contradictions with teachers' assistance in the teaching of organization, guidance, and by simulating a situation or designing a task. [6] Role play gives students a dynamic scenario, enable students the opportunity to speak and do, so that students in the activities can boost inspiration, develop problem-solving, therefore improve teaching effectiveness.

The role-playing experience method is suitable for teaching content which based on business service process, business reception, business banquet, visiting company, customer communication, farewell, and etc. Role design method and the grouping method which students sub-groups simultaneously implement the role of the exercise, so that each student can appreciate the status of the role are essential in those business activities.

Case Study Experience. Case study experience is based on teachers' leading students to simulate into the case provided, so that students use the knowledge to analyze the problem and solve the problem described in the case, and try to come up with ideas.

This requires teachers to master the practical work on the basic business transaction, such as job search, product promotion and more suitable for the use of case teaching topics compiled into cases, and with teacher's guidance and suggestion, require students to use English and business knowledge in the course to simulate and conclude the case.

\section{Research Significance and Expected Results}

The basic idea of designing teaching mode of business English course on constructivism is that students can make use of various resources in the process of learning business English with different kinds of experience. In the process of teaching, constructivism and experience theory emphasize student-centered method, stress on students' active exploration and active construction of knowledge, pay attention to the learning process, and put premium on the development of human beings in the interaction and communication. Through discussion, cooperation and communication, fully participate in the experience and feelings, students can play an initiative role to stimulate their potential of independent learning, extend business theory and enhance practical competence, and finally accomplish systematically self-completion of business English knowledge construction. 
Under the guidance of construcivism experience theory, the teaching mode of experiential business English couse will be applied in Enlish majors of seconday grade, if the quality of teaching results can be improved obviously, it can be extended to the teaching design and practice reform of the related business English correspondence course, business negotiation course and so on. According to the teaching effect of the constructive experiential business English course teaching mode, it can be expected that an objective research and relevant teaching reform will be conducted, the teaching plan will be formulated according to the practical teaching link, the syllabus will be revised, and the corresponding lectures with multimedia courseware will be prepared.

\section{Acknowledgement}

This research was financially supported by Teaching Research and Reform Fund of Engineering and Technical College of Chengdu University of Technology, project no. 2016-YY-JG44.

\section{References}

[1]Sarah Jones-Macziola, Greg White, Further Ahead—a communication skills course for Business English, Posts and Telecom Press, Beijing, 2007.

[2] Leo Jones, Working in English, Posts and Telecom Press, Beijing, 2007.

[3] Liu Fen, A Cognitive Study of Language and Language Teaching in English and Chinese, China WaterPower Press,Beijing, 2012.

[4] Liu Yuan, Experiencing Foreign Languages: Theory and Practice, Higher Education Press, 2012.

[5] Lou Hongliang, On the teaching model of constructivist experiential business English course taking the course of economics (English) as an example, Journal of Heilongjiang College of Education. 07 (2014) 168-169.

[6] Guo Hongyu, Cambridge business English (BEC) teaching under the guidance of constructivism, Journal of Inner Mongolia Normal University (Educational Science). 3(2008) 119-121. 